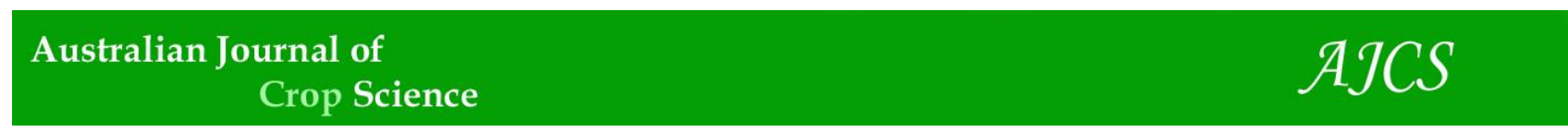

AJCS 10(9):1288-1296 (2016)

ISSN:1835-2707

DOI: $10.21475 /$ ajcs.2016.10.09.p7730

\title{
Evidence of association among floral and fruit traits and its implication on fruit size and shape in tomato (Solanum lycopersicum)
}

\author{
Nnungu, S. I ${ }^{1,2}$ and Uguru M.I ${ }^{2}$ \\ ${ }^{1}$ Department of Botany, University of Dar es Salaam, Dar es Salaam, Tanzania \\ ${ }^{2}$ Department of Crop Science, University of Nigeria, Nsukka, Nigeria
}

*Corresponding author: nnunguh@gmail.com

\begin{abstract}
The relationship and the magnitude of association among floral and fruit characters in tomato were investigated in this study. The mean value of fruit weight showed significant and positive correlation with all the floral traits with the exception of length of flower and style. The number of locules per fruit had the highest correlation value $\left(\mathrm{r}=0.984^{* *}\right)$ with fruit size. Path coefficient analysis revealed that number of locules per fruit has the highest positive direct effect $\left(\mathrm{p}=0.8086^{* *}\right)$ on fruit size. This was closely followed by ovary diameter $\left(\mathrm{p}=0.7942^{* *}\right)$ and stigma diameter $\left(\mathrm{p}=0.7685^{* *}\right)$. On the other hand, style length had the highest negative direct effect $\left(\mathrm{p}=-0.9147^{* *}\right)$ on fruit size. The fruit shape index showed significant positive correlation with the ovary shape index $(\mathrm{r}=$ $\left.0.835^{* *}\right)$ and the seed shape index $\left(\mathrm{r}=0.718^{* *}\right)$. However, fruit shape index was negatively and significantly correlated with ovary diameter $(r=-0.601 *)$, fruit diameter $\left(r=-0.576^{*}\right)$ and the seed diameter $\left(r=-0.519^{*}\right)$. The association mapping using 25 SNPs markers detected 9 markers with significant association with mean fruit weight, fruit length, fruit diameter, number of locule and fruit shape index. The SNP marker, Solyc11g039870 exhibited significant association with both fruit diameter, number of locules per fruit and fruit shape index. The variation in fruit diameter explained by the marker, Solyc11g039870 was higher than the variations in the number of locules per fruit and fruit shape index.
\end{abstract}

Keywords: Correlation, Path coefficient analysis, SNPs markers, tomato, Solanum lycopersicum.

Abbreviations: SNP_Single nucleotide polymorphism; K_Number of sub-population; QTL_Quantitative Trait loci; fw_fruit weight; LC_Locule number; FAS_Fasciated; S_Supersteak; BF_Beef florida; PR_Plumb Rio Grande.

\section{Introduction}

Plant geneticists are presently concentrating on identifying individual genes affecting complex agronomic traits like yield and fruit size. Genes involved in fruit size increment behave in an additive manner in different fruit developmental pathways, each contributing to the final fruit size (Tanksley, 2004). Developmental studies have shown that tomato fruit size is determined by the number of ovary cells before fertilization, number of successful fertilizations, number of cell divisions occur within the developing fruit after fertilization and the extent of cell enlargement (Zhang et al., 2006). Some of the implicated loci exert their effects through modulation of the size of the carpel and number of locules, fruit length, fruit diameter and number of seeds (Lippman and Tanksley, 2001). The development of tomato fruit begins with ovary development within the floral meristem. After successful pollination and fertilization, the tomato ovary develops into the fruit, which proceeds through stages of cell division, followed by rapid growth, mainly due to cell expansion (Zhang et al., 2006).

Majority of studies on inheritance of fruit size in tomatoes indicated that number of locules per fruit played a major role in fruit size increment. Li et al. (2007) studied the inheritance of number of locules per fruit and indicated that the trait is polygenically controlled. Gontijo et al. (1983) also reported that number of locules per fruit is related to fruit size.
Lippman and Tanksley (2011) identified six major QTLs namely $f w 1.1, f w 1.2, f w 2.1, f w 2.2, f w 3.1 / f w 3.2$ and $f w 11.3$, located on chromosomes 1, 2, 3 and 11, as major determinants of fruit size in tomato. Rodriguez et al. (2011) reported four important QTLs involved in fruit shape changes in tomato. The alleles, sun and ovate in chromosomes 1 and 3 are involved in regulating fruit elongation. Locule number (LC) and fasciated (FAS) on chromosomes 2 and 11 are involved in squatting the fruit shape. The QTL fw2.2 exert its effect on fruit size through its control on cell division in early fruit development stage, while the QTLs, fw11.3 and $l c 11.1$ exert their effects on fruit size through the control of locule number (Van der knaap and Tanksley, 2003)

The relationships between the final fruit size and the aforementioned QTLs have been studied yet, but no effort has been made, to date, to study the contributions of floral traits to the final fruit size. This has created a knowledge gap and the present study was initiated to fill the gap. The objectives of the study were; therefore, to investigate (1) the contributions of floral and fruit traits in determination of fruit size and (2) to use the generated information to guide tomato selection using the identified floral and fruit characters. 


\section{Results}

Correlation analysis of the floral and fruit related characters with the fruit size

The results of the correlation analysis are presented in Table 3. The correlation study showed that fruit size had highly significant correlations with the flower width, stalk width, style diameter, stigma length and diameter, ovary diameter, length, area and perimeter, number of locules per fruit and the diameter and length of the fruit. The number of locules per fruit had the highest correlation value with fruit size $(r=$ $0.9844 * *)$. This was closely followed by ovary perimeter $(\mathrm{r}=$ $0.9722 * *)$, ovary diameter $(r=0.9674 * *)$, ovary area $(r=$ $\left.0.9578^{* *}\right)$, stigma diameter $\left(\mathrm{r}=0.9535^{* *}\right)$ and style diameter $\left(\mathrm{r}=0.9491^{* *}\right)$. Fruit size had significant and negative correlated with the style length $\left(\mathrm{r}=-0.8840^{* *}\right)$, flower length $\left(\mathrm{r}=-0.8078^{* *}\right)$, number of seeds $\left(\mathrm{r}=-0.2386^{* *}\right)$. The relationship between style diameter and length, ovary size and shape and seed size and shape among tomato genotypes are shown in Fig 1.

\section{Correlation analysis of the ovary, seed and fruit shape index of tomato}

The correlation studies also revealed that the ovary shape index and seed shape index had highly significant positive correlation with the fruit shape index (Table 5). However, fruit shape index was negatively correlated with ovary diameter $\left(r=-0.601^{*}\right)$, fruit diameter $\left(r=-0.576^{*}\right)$ and seed diameter $(-0.519 *)$. The seed shape index was positively correlated with the ovary shape index $\left(\mathrm{r}=0.785^{* *}\right)$ and style length $\left(r=0.718^{* *}\right)$. On the other hand, seed shape index was negatively correlated with seed perimeter. The ovary shape index was negative and significantly correlated with the ovary diameter $\left(r=-0.715^{* *}\right)$, seed diameter $(r=-$ $\left.0.67^{* *}\right)$, ovary area $\left(\mathrm{r}=-0.628^{*}\right)$ and fruit diameter $(\mathrm{r}=-$ $0.622 *)$

\section{Path coefficient analysis of the floral and fruit related characters with the fruit size}

The path analysis revealed that number of locules per fruit and ovary diameter exerted maximum direct positive effects on fruit size (Table 4), while style length recorded the highest negative direct effect on fruit size. The residual factor that measures the extent of causal factors implicated in the path analysis has explained the variability of 0.0001833 .

\section{Marker-trait association}

Twenty five polymorphic SNPs markers were used. The association mapping results revealed that, the SNP marker, Solyc02g072540 was significantly $(\mathrm{P} \leq 0.05)$ associated with mean fruit weight (Table 6). The marker explained $13 \%$ of the mean fruit weight variation. The SNP marker, Solyc11g062000 mapping on chromosome 11 was significantly $(\mathrm{P} \leq 0.01)$ associated with fruit length. The marker explained approximately $89.3 \%$ of the fruit length. For the fruit width, the analysis revealed significant $(\mathrm{P} \leq$ 0.01) associations for SNPs markers, Solyc11g018580, Solyc11g020720, Solyc11g039870 and Solyc11g062000) located on chromosome 11. Each marker explained approximately $184 \%, 23 \%, 141.5 \%$ and $30.6 \%$, respectively of the fruit width variation. The results are summarized in Table 6.
Only SNP marker, Solyc11g039870 was significantly associated with the number of locules per fruit and explained $23 \%$ of number of locules per fruit variation. Fruit shape index was significantly $(\mathrm{P} \leq 0.05)$ associated with two SNPs markers. The first marker was Solyc11g018690 located on chromosome 11, which explained about $14.4 \%$ of the fruit shape index variation. The second marker was Solyc11-17 also mapping on chromosome 11 , which explained $18.3 \%$ of the fruit shape index variation. The results are presented in Table 6. The association mapping results confirmed the interrelation among the fruit size related characters. For example SNP marker, Solyc11g039870 located on chromosome 11 was significantly associated with fruit width, number of locules per fruit and fruit shape index. However, the variation in fruit diameter explained by the marker, Solyc11g039870 was higher than the variations in the number of locules per fruit and fruit shape index.

\section{Population structure of the tomato progenies}

Genotyping data generated using the 25 polymorphic SNP markers. The data were used for genetic structure analysis using the Bayesian clustering model implemented in the structure software. The result showed that DK reached the maximal value when $K=3$. The applied model indicated $K=$ 3 is the best number of sub-population (hereafter referred to as $\mathrm{Q}=3$, providing support for the existence of the three distinct clusters in our association panel. The $\mathrm{Q}$ matrix outputs of the three subpopulations were used for the association analysis. Each individual sample was represented by a single row broken into three-colored segments (red, green and blue). The results are presented in Fig 3 .

\section{Discussion}

Correlation analysis of the floral and fruit related characters with the fruit size

Fruit size is a complex entity associated with number of component characters including floral traits and other fruit size related components. It is part of the yield; therefore, is the crucial concern of the plant breeder and also the final factor, on which selection program is based. It is known that tomato varieties considerably vary in fruit size and floral traits. These variations can be attributed to both ontogenic changes in the flower traits and the environmental effects since floral traits are known to be quantitatively inherited (Oyiga et al., 2010). A study of association of the characters related to fruit size would assist in any selection targeting more than one character at a time. All changes in the fruit size must be accompanied by change in one or more fruit size related characters (Indu Rani et al., 2008). Therefore, improvement of one character results in simultaneous improvement of all the positively related characters. In tomato fruit size improvement, the knowledge of association between the floral and fruit size related traits and the final fruit size is of special significance. As fruit size and shape are influenced by many factors, information based only on the correlation among the contributing factors may produce misleading results as it measures only the mutual association between two variables. On the other hand, a combined study involving correlation and the path coefficient analysis would provide a more reliable means of partitioning the variation into the direct and indirect causes of the association between traits. 
Table 1. Mean values of the floral and fruit size traits in tomato used in the study.

\begin{tabular}{llllllllllllllllll}
\hline Tomato varieties & FL & FW & SW & SL & SLD & SGD & SGL & OD & OL & OA & OP & FL & FW & LC & NS & SFW \\
\hline W x R & 0.5226 & 0.1331 & 0.0455 & 0.4333 & 0.0156 & 0.0219 & 0.012 & 0.0836 & 0.1008 & 0.0776 & 0.3478 & 4.44 & 4.2 & 2.22 & 64.33 & 26.98 \\
R x W & 0.4969 & 0.1316 & 0.0446 & 0.4005 & 0.0158 & 0.0204 & 0.0095 & 0.0819 & 0.0947 & 0.0701 & 0.3402 & 4.52 & 4.33 & 2.44 & 73.56 & 29.56 \\
W x T & 0.4797 & 0.1302 & 0.0408 & 0.3914 & 0.015 & 0.021 & 0.0111 & 0.0824 & 0.0958 & 0.0717 & 0.344 & 4.76 & 4.29 & 2.33 & 74 & 29.37 \\
S & 0.7427 & 0.2452 & 0.1019 & 0.4252 & 0.1093 & 0.1192 & 0.0113 & 0.2434 & 0.1883 & 0.4407 & 0.8097 & 6.84 & 8.2 & 10.7 & 48.22 & 170.3 \\
BF & 0.4411 & 0.1618 & 0.0548 & 0.3466 & 0.0265 & 0.0341 & 0.0146 & 0.1102 & 0.1222 & 0.1209 & 0.4436 & 4.91 & 5.63 & 4.89 & 91.78 & 75.09 \\
PR & 0.4366 & 0.1656 & 0.0613 & 0.3458 & 0.0314 & 0.0353 & 0.0151 & 0.0963 & 0.1253 & 0.1249 & 0.4388 & 4.8 & 3.97 & 3.33 & 43.22 & 39.54 & 0.1109 \\
S x (W x R) & 0.5269 & 0.1528 & 0.0531 & 0.4307 & 0.0198 & 0.0256 & 0.0105 & 0.1009 & 0.1 & 0.1109 & 0.4049 & 5.18 & 4.88 & 4 & 62.33 & 41.79 \\
(W x R) x S & 0.5312 & 0.1424 & 0.0514 & 0.4352 & 0.02 & 0.0258 & 0.0115 & 0.09 & 0.0905 & 0.0918 & 0.3811 & 4.06 & 3.84 & 2.22 & 52.67 & 23.39 \\
PR x (R x W) & 0.5106 & 0.1454 & 0.0573 & 0.4157 & 0.0182 & 0.0249 & 0.0132 & 0.0862 & 0.1178 & 0.0917 & 0.3956 & 5.9 & 4.41 & 2.67 & 61.56 & 39.29 \\
PR x (W x R) & 0.5143 & 0.1454 & 0.0476 & 0.416 & 0.021 & 0.0317 & 0.0133 & 0.0936 & 0.1185 & 0.1048 & 0.4116 & 5.11 & 4.24 & 2.89 & 56.11 & 29.27 \\
PR x (W x T) & 0.4988 & 0.141 & 0.0523 & 0.4017 & 0.02 & 0.0288 & 0.0125 & 0.0847 & 0.1275 & 0.1044 & 0.4157 & 6.06 & 4.22 & 2.67 & 83.67 & 33.93 \\
BF x (W x T) & 0.5442 & 0.1549 & 0.0516 & 0.4482 & 0.0204 & 0.0263 & 0.0106 & 0.1007 & 0.1055 & 0.0975 & 0.3922 & 4.34 & 4.27 & 2.22 & 72.33 & 28.29 \\
\hline GRAND MEAN & 0.5205 & 0.1541 & 0.0552 & 0.4075 & 0.0277 & 0.0346 & 0.0121 & 0.1045 & 0.1161 & 0.1245 & 0.4263 & 4.99 & 4.74 & 3.53 & 65.33 & 47.21 \\
\hline
\end{tabular}

Table 2. Mean values of the floral and fruit shape related characters in tomato used in the study.

\begin{tabular}{|c|c|c|c|c|c|c|c|c|c|c|c|c|c|}
\hline Tomato varieties & OD & $\mathrm{OL}$ & $\mathrm{OA}$ & $\mathrm{OP}$ & SD & SL & SA & SP & FL & FD & OSI & SSI & FSI \\
\hline $\mathrm{W} \times \mathrm{R}$ & 0.0836 & 0.1008 & 0.0776 & 0.3478 & 0.1456 & 0.1729 & 0.0209 & 0.562 & 2.0409 & 1.4864 & 1.20527 & 1.18779 & 1.37309 \\
\hline $\mathrm{R} \times \mathrm{W}$ & 0.0819 & 0.0947 & 0.0701 & 0.3402 & 0.1548 & 0.1612 & 0.0206 & 0.549 & 2.04 & 1.73 & 1.15575 & 1.04134 & 1.17919 \\
\hline $\mathrm{W} \times \mathrm{T}$ & 0.0824 & 0.0958 & 0.0717 & 0.344 & 0.158 & 0.1748 & 0.0225 & 0.5718 & 2.27 & 1.66 & 1.16198 & 1.10601 & 1.36747 \\
\hline $\mathrm{S}$ & 0.2434 & 0.1883 & 0.4407 & 0.8097 & 0.2176 & 0.1737 & 0.0314 & 0.6908 & 3.47 & 5.34 & 0.77348 & 0.79842 & 0.64981 \\
\hline $\mathrm{BF}$ & 0.1102 & 0.1222 & 0.1209 & 0.4436 & 0.1978 & 0.1607 & 0.0264 & 0.6293 & 3.57 & 3.334 & 1.10865 & 0.8125 & 1.07079 \\
\hline PR & 0.0963 & 0.1253 & 0.1249 & 0.4388 & 0.1327 & 0.2259 & 0.0259 & 0.628 & 3.14 & 2.45 & 1.30096 & 1.70234 & 1.28163 \\
\hline$S \times(W \times R)$ & 0.1009 & 0.1059 & 0.0982 & 0.3949 & 0.1753 & 0.1752 & 0.0253 & 0.6053 & 2.915 & 2.64 & 1.05021 & 0.99937 & 1.10417 \\
\hline$P R \times(R \times W)$ & 0.0862 & 0.1178 & 0.0917 & 0.3956 & 0.1395 & 0.2215 & 0.0238 & 0.6213 & 3.2 & 1.6889 & 1.36576 & 1.58781 & 1.89474 \\
\hline PR x (W x R) & 0.0935 & 0.1185 & 0.1048 & 0.4116 & 0.1597 & 0.2113 & 0.0257 & 0.6272 & 3.3 & 2.08 & 1.26699 & 1.3232 & 1.58654 \\
\hline$P R \times(W \times T)$ & 0.0847 & 0.1275 & 0.1044 & 0.4157 & 0.1581 & 0.1988 & 0.0245 & 0.6104 & 2.83 & 1.67 & 1.50494 & 1.25692 & 1.69461 \\
\hline $\mathrm{BF} \times(\mathrm{W} \times \mathrm{T})$ & 0.1007 & 0.1055 & 0.0975 & 0.3922 & 0.1803 & 0.1595 & 0.0247 & 0.6057 & 2.14 & 2.09 & 1.04783 & 0.88447 & 1.02392 \\
\hline GRAND MEAN & 0.1002 & 0.1149 & 0.1165 & 0.4132 & 0.1583 & 0.1826 & 0.0234 & 0.5900 & 2.7159 & 2.2507 & 1.2053 & 1.1905 & 1.2959 \\
\hline
\end{tabular}

$\mathrm{D}=$ Ovary diameter, $\mathrm{OL}=$ Ovary length, OA = Ovary area, OP = Ovary perimeter, $\mathrm{SD}=$ Seed diameter, SL= Seed length, $\mathrm{SA}=$ Seed area, SP $=$ Seed perimeter, FL = Fruit length, FD = Fruit diameter, OSI = Ovary shape index, SSI = Seed shape index, FSI = Fruit shape index. W x R = Wild x Roma; R x W = Roma x Wild; W x T = Wild x Tropica; S = Supersteak; BF = Beef (florida); PR = Plumb (Rio grande) 


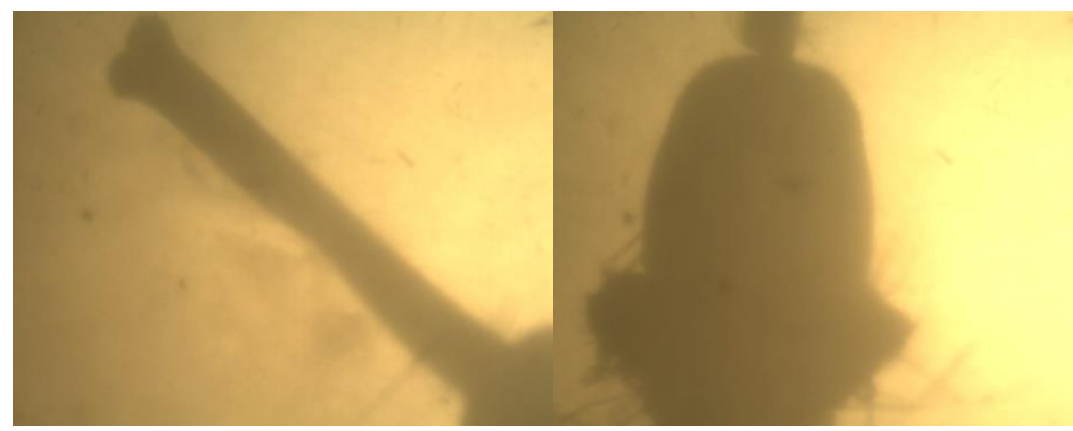

PR

a.

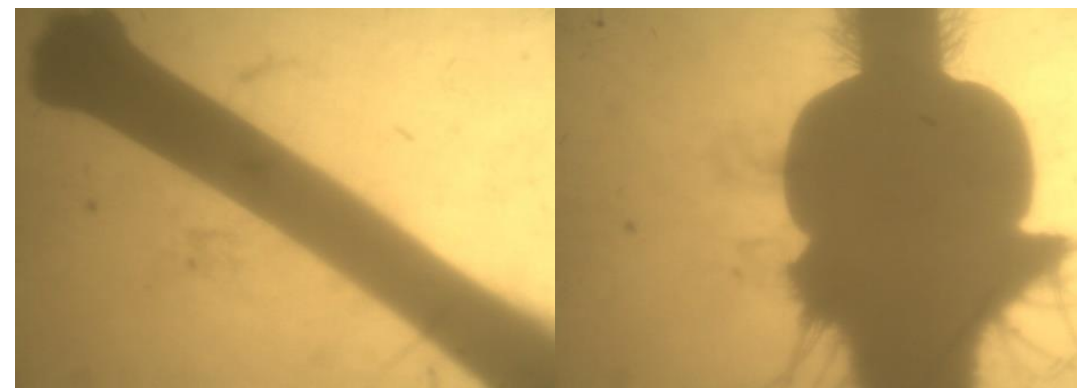

BF

a.

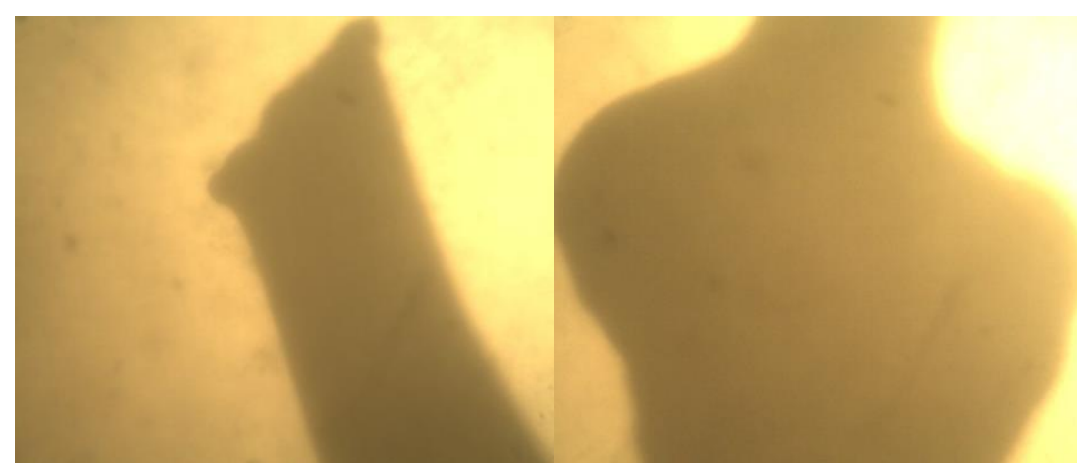

S

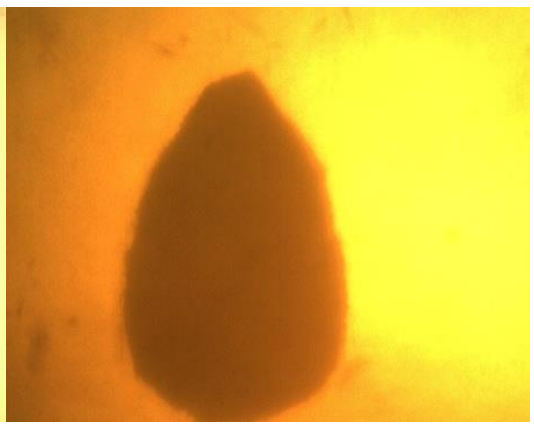

c.

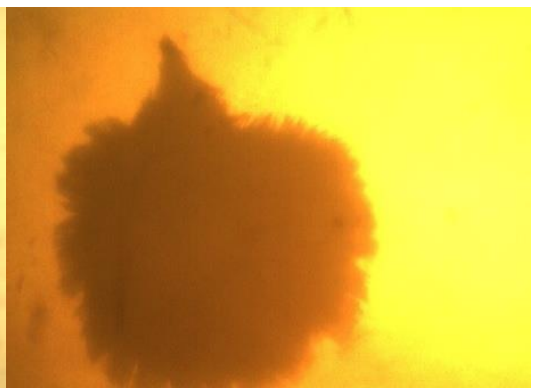

c.

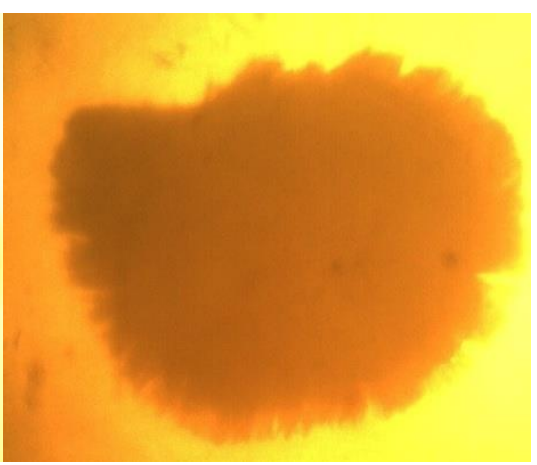

b.

c.

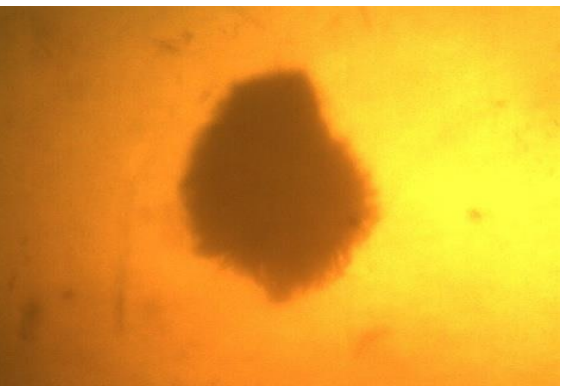

b.

c.

w

a.

Fig 1. Tomato parents used in this work showing the relationship in size and shape, a. style and stigma, b. ovary and c. seed. PR = Plumb (Rio grande); BF = Beef (Florida) round , $\mathrm{S}=$ Supersteak and $\mathrm{W}=$ Wild tomato 


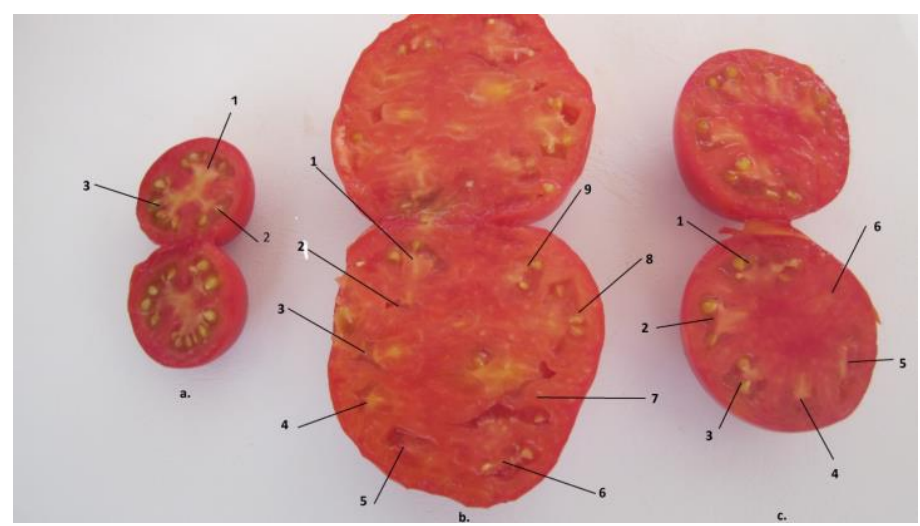

Fig 2. Fruit morphology and locule number for tomato parents (a and b) used for this work to produce hybrid c.

Fruit size was significantly correlated with fruit length, fruit width, as reported by Prashanth et al. (2008) and Singh (2005). Also the locule number per fruit exhibited significant positive correlation with mean fruit weight. These results are in line with Singh (2005), Singh (2007) and Prashanth et al. (2008). With the exception of flower and style lengths, all the floral traits were positively correlated with fruit size. A positive correlation shows that the changes of the two variables are in the same direction, implying that an increase in one variable will lead to increase of the other. Among the floral traits measured, ovary perimeter had the highest positive correlation with fruit size. This was closely followed by ovary diameter, ovary area, stigma diameter and style diameter. Earlier workers reported that fruit size is developmentally related to the ovary size, from which the fruit developed (Frary et al., 2000, Ashman and Majestic, 2006). The positive relationship between the perimeter and area of the ovary, diameters of the ovary, stigma and style and the fruit size means that increase in perimeter and area of ovary, diameters of the ovary, stigma and style would correspondingly lead to increase in fruit size. Webb and Lloyd (1986) reported that large stigma diameter provides a larger receptive surface area for pollen deposition. Therefore, large receptive area of the stigma is an advantage as it is able to capture higher number of pollen grains. The large style diameter and shorter style length tends to ease the movement of male gamete to the ovary. This indicates that selection of tomato varieties with larger perimeter and area of ovary, diameters of the ovary, stigma and style will be a reliable strategy for fruit size improvement in tomato. The fruit size was negatively correlated with the style length $(\mathrm{r}=$ $0.8840 * *)$, flower length $\left(\mathrm{r}=-0.8078^{* *}\right)$, number of seeds $(\mathrm{r}$ $\left.=-0.2386^{* *}\right)$, an indication that tomato plants with pronounced flower and style lengths and profuse seed production will be endowed with small fruit size.

\section{Path coefficient analysis of the floral and fruit related characters with the fruit size}

Among the traits subjected to path analysis, locule number per fruit had a very high direct effect on fruit size. The direct effects of the ovary diameter and stigma diameter on fruit size were also appreciably high. The highest positive direct effect of locule number had already been documented ( $\mathrm{Li}$ et al., 2007). The characters with high direct effects on fruit size should be given substantial recognition in selection for increased fruit size.

\section{Correlation analysis of the ovary, seed and fruit shape index of tomato}

Fruit shape index was significantly correlated with the ovary shape index and seed shape index. This result agrees with Perin et al. (2002) and Eduardo et al. (2007) who reported a high positive correlation between ovary and mature fruit morphology in melon, indicating that fruit shape is predominantly determined pre-anthesis. Van dar Knaap and Tanksley (2001) and Chakrabarti et al. (2013) reported that changes in fruit morphology manifest themselves either before or after anthesis. Fruit shape index was negatively correlated with ovary diameter $(r=-0.601 *)$, fruit diameter $(r$ $\left.=-0.576^{*}\right)$ and seed diameter $(\mathrm{r}=-0.519 *)$. Similar results were reported by Monforte et al. (2004) and Eduardo et al. (2007). On the other hand, fruit shape index was positively correlated with the fruit length. Fruit shape index below 1 indicates round fruit shape and fruit shape index above 1 indicate ovate fruit shape. The elongated shape is generally also highly correlated with the length of the fruit but not with the diameter (Monforte et al., 2004; Eduardo et al., 2007), suggesting that longitudinal growth is the major factor of the final shape. On the other hand, the flat round shape is highly correlated with diameter of the fruit. The parent, Supersteak had the fruit shape index of less than 1, while Plumb had the fruit shape index of greater than 1 .

\section{Marker-trait association}

The association mapping approach undertaken allowed detection of 9 SNPs markers associated with five fruit traits namely; fruit weight, fruit length, fruit width, locule number and fruit shape index that are essential for fruit size improvement. The association between SNPs markers and fruit traits were mostly localized on chromosome 11, but this is partly due to the higher number of markers representing on chromosome 11 than the other chromosomes.

Fruit size is a quantitatively inherited trait controlled by up to 28 QTLs, even though QTL analyses in previous studies revealed that most $(67 \%)$ phenotypic variation in fruit size could be attributed to six major loci ( $f w 1.1, f w 1.2$, fw2.1, fw2.2, fw3.2 and fw11.3) localized on chromosomes 1, 2, 3 and 11 (Lippman and Tansley, 2001; Causse et al., 2004 and Munoz et al., 2011). The association mapping analysis in this study confirmed two of the above loci ( $f w 2.2$ and fw11.3).

The association mapping detects and locates QTLs based on the strength of the correlation between mapped SNPs markers and traits (Mackay and Powell, 2007). Association mapping 
Table 3. Correlation coefficients for floral traits and fruit size components among tomato varieties.

\begin{tabular}{|c|c|c|c|c|c|c|c|c|c|c|c|c|c|c|c|c|}
\hline & FLL & $\mathrm{FW}$ & SW & SL & SYD & SGD & SGL & OD & $\mathrm{OL}$ & $\mathrm{OA}$ & $\mathrm{OP}$ & NS & SEW & LN & FRL & FD \\
\hline FLL & 1 & & & & & & & & & & & & & & & \\
\hline FW & $-0.77 * *$ & 1 & & & & & & & & & & & & & & \\
\hline SW & $-0.78^{* *}$ & $0.95 * *$ & 1 & & & & & & & & & & & & & \\
\hline SL & $0.97 * *$ & $-0.87 * *$ & $-0.88 * *$ & 1 & & & & & & & & & & & & \\
\hline SYD & $-0.80 * *$ & $0.846^{* *}$ & $0.889 * *$ & $-0.87 * *$ & 1 & & & & & & & & & & & \\
\hline SGD & $-0.79 * *$ & $0.852 * *$ & $0.883^{* *}$ & -0.86 ** & $0.996 * *$ & 1 & & & & & & & & & & \\
\hline SGL & -0.18 & 0.063 & 0.213 & -0.145 & 0.016 & 0.014 & 1 & & & & & & & & & \\
\hline OD & $-0.78 * *$ & $0.897 * *$ & $0.888 * *$ & $-0.86 * *$ & $0.977 * *$ & $0.981 * *$ & -0.066 & 1 & & & & & & & & \\
\hline $\mathrm{OL}$ & $-0.78 * *$ & $0.924 * *$ & $0.955^{* *}$ & $-0.87 * *$ & $0.894 * *$ & $0.908 * *$ & 0.244 & $0.891 * *$ & 1 & & & & & & & \\
\hline $\mathrm{OA}$ & $-0.80 * *$ & $0.893 * *$ & $0.908 * *$ & $-0.88 * *$ & $0.990 * *$ & $0.993 * *$ & -0.024 & $0.990 * *$ & $0.922 * *$ & 1 & & & & & & \\
\hline OP & $-0.81 * *$ & $0.936 * *$ & $0.944 * *$ & $-0.89 * *$ & $0.968 * *$ & $0.976 * *$ & 0.069 & $0.976^{* *}$ & $0.966 * *$ & $0.98 * *$ & 1 & & & & & \\
\hline NS & 0.28 & -0.240 & -0.144 & 0.275 & -0.351 & -0.372 & 0.393 & -0.361 & -0.265 & -0.371 & -0.330 & 1 & & & & \\
\hline SEW & -0.31 & $0.603 *$ & 0.490 & -0.398 & 0.352 & 0.405 & 0.115 & 0.444 & $0.576^{*}$ & 0.426 & $0.51^{* *}$ & -0.002 & 1 & & & \\
\hline LN & $-0.79 * *$ & $0.903 * *$ & $0.921 * *$ & $-0.85^{* *}$ & $0.949 * *$ & $0.950^{* *}$ & 0.117 & $0.954 * *$ & $0.917 * *$ & $0.95 * *$ & $0.96^{* *}$ & -0.209 & 0.492 & 1 & & \\
\hline FRL & $-0.71 * *$ & $0.846^{* *}$ & $0.900 * *$ & $-0.79 * *$ & $0.786 * *$ & $0.803 * *$ & 0.457 & $0.788 * *$ & $0.923 * *$ & $0.81 * *$ & $0.87 * *$ & -0.072 & $0.64 * *$ & $0.872^{* *}$ & 1 & \\
\hline FD & $-0.67 * *$ & $0.853 * *$ & $0.794 * *$ & $-0.73 * *$ & $0.637 *$ & $0.642 *$ & 0.293 & $0.703 * *$ & $0.756 * *$ & $0.67 * *$ & $0.74 * *$ & 0.002 & $0.569 *$ & $0.804 * *$ & $0.83 * *$ & 1 \\
\hline SWF & $-0.81 * *$ & $0.914 * *$ & $0.919 * *$ & $-0.88 * *$ & $0.949 * *$ & $0.953 * *$ & 0.117 & $0.967 * *$ & $0.919 * *$ & $0.95 * *$ & $0.97 * *$ & -0.238 & $0.502 *$ & $0.984 * *$ & $0.88 * *$ & $0.83 * *$ \\
\hline
\end{tabular}

$\mathrm{FLL}=$ Flower length, $\mathrm{FW}=$ Flower width, $\mathrm{SW}=\mathrm{Stalk}$ width, $\mathrm{SL}=\mathrm{Style}$ length, $\mathrm{SYD}=$ Style diameter, $\mathrm{SGD}=$ Stigma diameter, $\mathrm{SGL}=\mathrm{Stigma}$ length, $\mathrm{OD}=\mathrm{Ovary}$ diameter, OL $=\mathrm{Ovary}$ length, $\mathrm{OA}=\mathrm{Ovary}$ area, $\mathrm{NS}=\mathrm{Number}$ $\mathrm{FLL}=$ Flower length, $\mathrm{FW}=$ Flower width, $\mathrm{SW}=$ Stalk width, $\mathrm{SL}=$ Style length, $\mathrm{SYD}=$ Style diant
of seeds, $\mathrm{SEW}=$ Seed weight, $\mathrm{LN}=$ Locule number per fruit, $\mathrm{FRL}=$ Fruit length, $\mathrm{FD}=$ Fruit width.
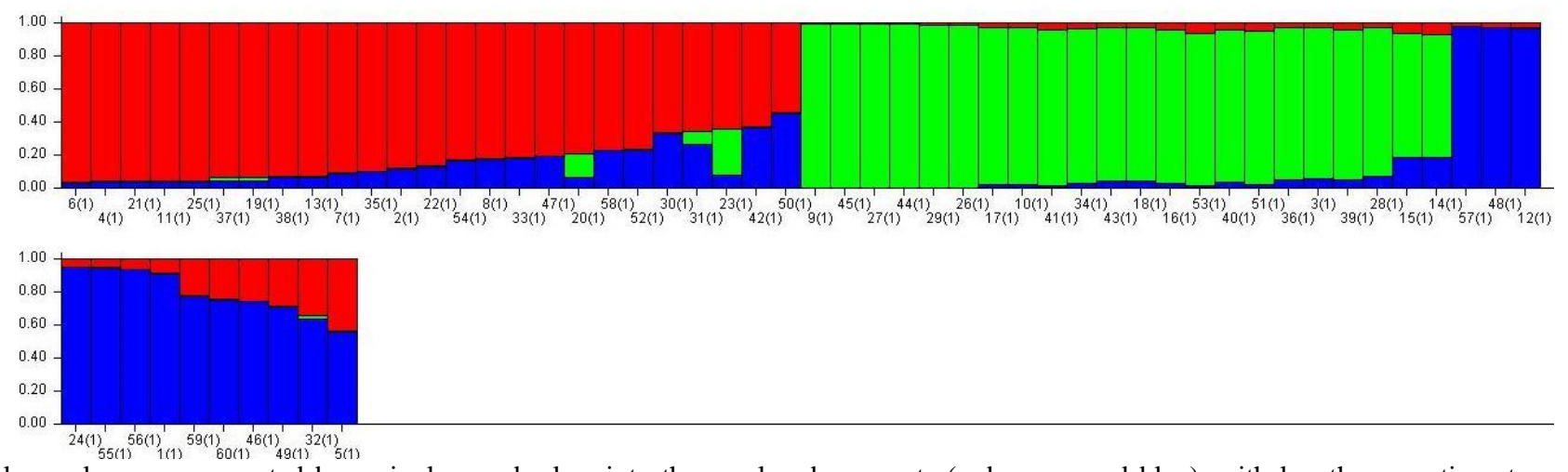

Fig 3. Each individual sample was represented by a single row broken into three-colored segments (red, green and blue), with length proportions to each of the two inferred population subgroups. 
Table 4. Partitioning the phenotypic correlation into direct (bold) and indirect effect of the fruit size components.

\begin{tabular}{|c|c|c|c|c|c|c|c|c|c|c|c|}
\hline & FLL & $\mathrm{FW}$ & SW & SL & SGL & OD & $\mathrm{OL}$ & NS & SEW & $\mathrm{LN}$ & $\mathrm{rg}$ \\
\hline FLL & 0.3774 & -0.0880 & -0.1342 & -0.8905 & 0.0243 & -0.6221 & -0.0522 & 0.0166 & 0.0709 & -0.6295 & $-0.81 * *$ \\
\hline FW & -0.2922 & 0.1136 & 0.1634 & 0.7971 & -0.0084 & 0.7130 & 0.0617 & -0.0145 & -0.1380 & 0.7303 & $0.91 * *$ \\
\hline SW & -0.2935 & 0.1076 & 0.1726 & 0.8076 & -0.0283 & 0.7059 & 0.0638 & -0.0087 & -0.1122 & 0.7453 & $0.92 * *$ \\
\hline SL & 0.3674 & -0.0990 & -0.1524 & -0.9147 & 0.0193 & -0.6893 & -0.0582 & 0.0166 & 0.0910 & -0.6885 & $-0.88 * *$ \\
\hline SGL & -0.0691 & 0.0072 & 0.0368 & 0.1330 & -0.1328 & -0.0527 & 0.0163 & 0.0237 & -0.0264 & 0.0949 & 0.117 \\
\hline OD & -0.2956 & 0.1020 & 0.1534 & 0.7938 & 0.0088 & 0.7942 & 0.0595 & -0.0218 & -0.1016 & 0.7718 & $0.97 * *$ \\
\hline OL & -0.2953 & 0.1051 & 0.1649 & 0.7972 & -0.0324 & 0.7079 & 0.0667 & -0.0160 & -0.1318 & 0.7420 & $0.92 * *$ \\
\hline $\mathrm{OA}$ & -0.3042 & 0.1016 & 0.1568 & 0.8102 & 0.0033 & 0.7864 & 0.0616 & -0.0224 & -0.0976 & 0.7707 & $0.95 * *$ \\
\hline NS & 0.1043 & -0.0273 & -0.0249 & -0.2524 & -0.0522 & -0.2872 & -0.0177 & 0.0602 & 0.0006 & -0.1696 & -0.24 \\
\hline SEW & -0.1170 & 0.0686 & 0.0847 & 0.3642 & -0.0153 & 0.3530 & 0.0385 & -0.0001 & -0.2287 & 0.3980 & $0.50 *$ \\
\hline LN & -0.2938 & 0.1026 & 0.1591 & 0.7788 & -0.0156 & 0.7580 & 0.0612 & -0.0126 & -0.1125 & 0.8086 & $0.98 * *$ \\
\hline
\end{tabular}

$\mathrm{R}=0.0001833$, ** Correlation is significant at 0.01 level, $*$ Correlation is significant at 0.05 level. FLL $=$ Flower length, FW $=$ Flower width, $\mathrm{SW}=\mathrm{Stalk}$ width, $\mathrm{SL}=\mathrm{Style}$ length, $\mathrm{SYD}=\mathrm{Style}$ diameter, $\mathrm{SGD}=\mathrm{Stigma}$ diameter, $\mathrm{SGL}=$ Stigma length, $\mathrm{OD}=$ Ovary diameter, $\mathrm{OL}=$ Ovary length, $\mathrm{OA}=$ Ovary area, $\mathrm{NS}=$ Number of seeds, $\mathrm{SEW}=$ Seed weight, $\mathrm{LN}=$ Locule number per fruit, $\mathrm{R}=\mathrm{Residual}$ effect.

Table 5. Correlation coefficient analyses between floral and fruit shapes related characteristics among tomato varieties.

\begin{tabular}{|c|c|c|c|c|c|c|c|c|c|c|c|c|c|}
\hline & OD & $\mathrm{OL}$ & $\mathrm{OA}$ & OP & SD & SL & SA & SP & FL & FD & OSI & SSI & FSI \\
\hline OD & 1 & & & & & & & & & & & & \\
\hline $\mathrm{OL}$ & $0.898 * *$ & 1 & & & & & & & & & & & \\
\hline $\mathrm{OA}$ & $0.990^{* *}$ & $0.928 * *$ & 1 & & & & & & & & & & \\
\hline $\mathrm{OP}$ & $0.978 * *$ & $0.968 * *$ & $0.988 * *$ & 1 & & & & & & & & & \\
\hline SD & $0.745 * *$ & $0.658 * *$ & $0.680 * *$ & $0.721 * *$ & 1 & & & & & & & & \\
\hline SL & -0.014 & 0.346 & 0.053 & 0.158 & -0.027 & 1 & & & & & & & \\
\hline SA & $0.650 * *$ & $0.762 * *$ & $0.635^{*}$ & $0.723 * *$ & $0.818 * *$ & $0.528 *$ & 1 & & & & & & \\
\hline SP & $0.598 *$ & $0.759 * *$ & $0.591 *$ & $0.691 * *$ & $0.755^{* *}$ & $0.617 *$ & $0.988 * *$ & 1 & & & & & \\
\hline FL & 0.447 & $0.710 * *$ & 0.459 & $0.578 *$ & 0.511 & $0.694 * *$ & $0.777 * *$ & $0.827 * *$ & 1 & & & & \\
\hline FD & $0.927 * *$ & $0.891 * *$ & $0.908 * *$ & $0.936 * *$ & $0.807 * *$ & 0.115 & $0.758 * *$ & $0.711 * *$ & $0.666^{* *}$ & 1 & & & \\
\hline OSI & $-0.715 * *$ & -0.361 & $-0.628 *$ & $-0.569 *$ & $-0.67 * *$ & 0.497 & -0.344 & -0.241 & 0.042 & $-0.622 *$ & 1 & & \\
\hline SSI & -0.457 & -0.145 & -0.363 & -0.318 & $-0.70 * *$ & $0.718 * *$ & -0.183 & -0.077 & 0.171 & -0.403 & $0.785^{* *}$ & 1 & \\
\hline FSL & $-0.601 *$ & -0.275 & $-0.544 *$ & -0.474 & $-0.52 *$ & 0.597 & -0.166 & -0.038 & 0.161 & $-0.576^{*}$ & $0.835^{* *}$ & $0.718 * *$ & 1 \\
\hline
\end{tabular}


Table 6. SNPs Marker loci associated with fruit traits and their explained phenotypic variation.

\begin{tabular}{llllllll}
\hline Trait & Marker & Locus & Site & $\mathrm{F}$ & $\mathrm{p}$ & Error df & Marker $R^{2}$ \\
\hline SFW & Solyc02g072540 & 2 & 72540 & 3.68445 & $0.03562^{*}$ & 39 & 0.13588 \\
FL & Solyc11g062000 & 11 & 62000 & 14.14308 & $2.41 \mathrm{E}-05^{* *}$ & 44 & 0.8925 \\
FW & Solyc11g018580 & 11 & 18580 & 25.77063 & $5.65 \mathrm{E}-08^{* *}$ & 46 & 1.84834 \\
FW & Solyc11g020720 & 11 & 20720 & 5.50779 & $0.00717^{* *}$ & 51 & 0.23256 \\
FW & Solyc11g039870 & 11 & 39870 & 34.16942 & $1.31 \mathrm{E}-09^{* *}$ & 48 & 14.15861 \\
FW & Solyc11g062000 & 11 & 62000 & 40.39903 & $3.13 \mathrm{E}-10^{* *}$ & 44 & 3.06444 \\
LN & Solyc11g039870 & 11 & 39870 & 14.88021 & $1.23 \mathrm{E}-05^{* *}$ & 48 & 0.23024 \\
FSI & Solyc11g018690 & 11 & 18690 & 3.86104 & $0.02802^{*}$ & 52 & 0.14474 \\
FSI & Solyc11g039870 & 11 & 39870 & 3.27283 & $0.04753^{*}$ & 48 & 0.18348 \\
MFW = Single fruit weight, FL = Fruit length, FW = Fruit width and LN = Locule number, *Significant at 0.05 and **Significant at 0.01.
\end{tabular}

related to five fruit size characters were identified using 25 SNPs markers. Out of the 25 SNPs markers only 9 markers were associated with mean fruit weight, fruit length, fruit width, number of locules per fruit and fruit shape index. The results indicated that these nine loci may be stably related to the traits. Of all of the studied markers, one SNP marker was co-localized by three fruit size characters, namely, fruit width, number of locules per fruit and fruit shape index. Such co-localization of association for several fruit traits was found in previous studies (Zhao et al., 2011 and Bergelson and Roux, 2010). This might be related to pleiotropic effects of the same genes or to genetic linkage as earlier reported for QTL (Lecomte et al., 2004). All the markers detected are recommended for the fruit size improvement breeding program in tomato.

\section{Materials and Methods}

\section{Plant materials and population development}

The experimental materials comprised of advanced hybrids raised from inter-specific crosses between cultivated tomatoes (Roma VF and Tropica) and the wild tomato relative, Solanum pimpinefollium ( $\mathrm{W} \times \mathrm{R}, \mathrm{R} \times \mathrm{W}$ and $\mathrm{W} \times \mathrm{T}$ ). The advanced hybrids were crossed with a large fruited inbred tomato variety, Supersteak (S) imported from the United states of America (USA), Beef (Florida) (BF) and Plumb (Rio grande) (PR) varieties in a modified three-way cross to produce $F_{1}$ hybrids. The advanced hybrids served as the pollen parent while the Supersteak, Beef and Plumb were the seed parents. The $F_{1}$ hybrids were self-fertilized to produce the $F_{2}$ populations as a segregating population. The experiments were carried out in the Department of Crop Science screenhouse, University of Nigeria, Nsukka, located in the derived savannah zone (Latitude $0.6^{\circ} 52 \mathrm{~N}$, longitude $07^{\circ} 24 \mathrm{E}$ with an altitude of $447.26 \mathrm{~m}$ above sea level) in 2013 and 2014. The seeds were raised in nursery boxes filled with sterilized soil, well cured poultry manure and river sand mixed at a ratio of 3:2:1 by volume. The seedlings were transplanted into polythene bags arranged in the screen house four weeks after planting.

\section{Floral and fruit traits measurements}

For the studies on the floral traits, 20 flowers were harvested from each genotype and immediately placed into the plastic bags and taken to the laboratory for the measurements of the floral characteristics at anthesis. Flowers were cut longitudinally to expose the ovaries and the other female parts. The floral traits measured were; width and length of the flower, diameter and length of the stigma, diameter and length of the style, diameter, length, area and perimeter of the ovary. The shape index was obtained as the ratio of the length and the diameter of the traits measured (Brewer et al., 2006). The measurements were done using Moticam 2 with Motic Images Plus 2.0 software. Matured fruits were harvested for the measurement of the following fruit characters: fruit length, fruit diameter, number of locules and fruit weight. Fruit length was obtained by cutting the fruit longitudinally and measured in centimetres from the point of attachment to the blossom end. Fruit diameter was obtained by cutting the fruit transversely and measured in centimetres. The number of locules per fruit was obtained by counting. The fruit shape index was obtained by dividing the average fruit length with the average fruit diameter.

\section{DNA extraction}

Leaf tissue was used to extract total genomic DNA from parents (advanced interspecific hybrid and supersteak) and the $94 \mathrm{~F}_{2}$ populations arising from the crosses. The extraction of DNA followed the modified mini preparation protocol described by Doyle and Doyle (1990) with minor revisions. The extraction was done in the Department of Bioscience, International Institute of Tropical Agriculture (IITA), Ibadan, Nigeria.

\section{Single nucleotides polymorphism (SNP) markers}

Tomato genotypes were genotyped with 45 SNP markers. The SNPs markers were downloaded from the Tomato SNPs Database (SolCAP tomato collection). SNP marker selection and assay design were performed according to the procedures of Chao et al. (2010). The SNPs were selected mainly from chromosomes that are related with fruit size and shape (chromosomes 2, 3 and 11). A total of 250ng of genomic DNA per genotype was used for the SNP genotyping at the Inqaba Biotech, Pretoria, South Africa using the Sequenom Mass Array Iplex Platform following the manufacturer's protocol (Gabriel et al., 2009).

\section{Data analysis}

The floral and fruit size and shape related traits were subjected to correlation analysis using the computer statistical software package, SPSS version 20. Path coefficient analyses were carried out to show direct and indirect effects (magnitude and significance) of the floral and fruit traits on the fruit size using the SASS statistical package. QTL association mapping was done using Trait Analysis by Association, Evolution and Linkage (TASSEL 3.0 version software). The QTLs underlying fruit size such as mean fruit weight, fruit length, fruit width, number of locules per fruit and fruit shape index were tagged. The population structure was estimated with the model-based (Bayesian) cluster software, STRUCTURE 2.33 version. 


\section{Conclusions}

From the results obtained, number of locules per fruit, perimeter and diameter of ovary, stigma and style diameter share the direct link with the increase in fruit size in tomato. The single nucleotides polymophism (SNPs) markers analysis implicated mean fruit weight, number of locules per fruit, fruit length, fruit diameter and fruit shape index on chromosome 2 and 11 as important determinants of fruit size. The result also indicated 9 markers had significant association with the mean fruit weight, fruit length, fruit width, number of locules per fruit and fruit shape index. Therefore, all of these markers detected are recommended for the fruit size improvement breeding program in tomato.

\section{Acknowledgements}

The authors would like to acknowledge the TRECCAFRICA scholarship program for the $\mathrm{PhD}$ scholarship granted the corresponding author at University of Nigeria, Nsukka. Also they wish to acknowledge the University of Dar es Salaam for providing research funds for the present study.

\section{References}

Ashman T, Majetic C (2006) Genetic constraints on floral evolution: a review and evolution of patterns. Heredity. 96 (5): 343-352.

Bergelson J, Roux F (2010) Towards identifying genes underlying ecologically relevant traits in Arabidopsis thaliana. Nat Rev Genet. 11:867-879.

Brewer M, Lang L, Fujimura K, Dujmovic N, Gray S, Van der Knaap E (2006) Development of a controlled vocabulary and software application to analyze fruit shape variation in tomato and other plant species. Plant Physiol. 141: 15-25.

Causse M, Saliba-Colombani V, Lecomte L, Duffe P, Rousselle P, Buret M (2004) QTL analysis of fruit quality in fresh market tomato: a few chromosome regions control the variation of sensory and instrumental traits. J Exp Bot. 53: 2089-2098.

Chakrabarti M, Zhang N, Sauvage C (2013) A cytochrome P450 regulates a domestication trait incultivated tomato. Proc Natl Acad Sci USA. 110: 17125-17130.

Chao S, Zhang W, Akhunov E, Sherman J, Ma Y, Luo MC, Dubcovsky J (2009) Analysis of gene-derived SNP marker polymorphism in US wheat (Triticum aestivum L.) cultivars. Mol Breed. 23:23-33.

Doyle JJ, Doyle JL (1990) Isolation of Plant DNA from Fresh

Tissue. Focus. 12:13-15.

Eduardo I, Arus P, Monforte AJ, Obando J, Fernandez-Trujillo JP, Martinez JA, Alarcon AL, Alvarez JM, Van der Knaap E (2007) Estimating the genetic architecture of fruit quality traits in melon using a genomic library of near isogenic lines. $\mathrm{J}$ Amer Soc Hortic Sci. 132: 80-89.

Frary A, Nesbitt TC, Grandillo S, Van der Knaap E, Cong B, Liu J, Meller J, Elber R, Alpert K B, Tanksley SD (2000) fw2.2: a quantitative trait locus key to the evolution of tomato fruit size. Science. 289: 85-88.

Gabriel S, Ziaugra L, Tabbaa D (2009) SNP Genotyping Using the Sequenom MassARRAY iPLEX Platform. Curr Prot Hum Genet. 2.12.1-2.12.18.

Indu Rani C, Veeraragavanthatham D, Sanjutha S (2008) Studies on correlation and path coefficient analysis on yield attributes in Root knot nematode resistant $\mathrm{F}_{1}$ hybrids of tomato. J Appl Sci Res. 4(3):287-295.
Lecomte L, Saliba-Colombani V, Gautier A, Gomez-Jimenez MC, Duffe P, Buret M, Causse M (2004) Fine mapping of QTLs of chromosome 2 affecting the fruit architecture and composition of tomato. Mole Breed. 13:1-14.

Li Y, Li T, Wang D (2007) Studies on the inheritance of locule formation in tomatoes (Lycopersicon esculentum. Mill.). J Genet Gen. 34(11): 1028-1036.

Lippman Z, Tanksley SD (2001) Dissecting the genetic pathway to extreme fruit size in tomato using a cross between the small-fruited wild species Lycopersicon pimpinellifolium and L.esculentum var. giant heitloom. Genetics. 158:413-422.

Mackay L, Powell W (2007) Methods for linkage disequilbrium mapping in crops. Trend Plant Sci. 12:57-63.

Monforte AJ, Oliver M, Gonzalo MJ, Alvarez JM, DolcetSanjuan R, Arus P (2004) Identification of quantitative trait loci involved in fruit quality traits in melon (Cucumis melo L.). Theor Appl Genet. 108:750-758.

Muños S, Ranc N, Botton E, Bérard A, Rolland S, Duffé P, Carretero Y, Le Paslier MC, Delalande C, Bouzayen M, Brunel D, Causse M (2011) Increase in tomato locule number is controlled by two SNPs located near WUSCHEL. Plant Physiol. 156: 2244-2254.

Oyiga BC, Uguru MI, Aruah CB (2010) Studies on the floral traits and their implications on pod and seed yields in bambaragroundnut (Vignasubterrenea $(\mathrm{L}$. ) Verdc). Aust J Crop Sci. 4(2):91-97.

Perin C, Hagen LS, Giovinazzo N, Besombes D, Dogimont C, Pitrat M (2002) Genetic control of fruit shape acts prior to anthesis in melon (Cucumis melo L.). Molecular Genetics and Genomics. 266: 933-941.

Prashanth S, Jaiprakashnaraya R, Ravindra M, Madalageri MB (2008) Correlation and Path analysis in Tomato (Lycopersicumesculentum Mill.). Asian J Hortic. 3(2): $403-$ 408.

Rodríguez GR, Muños S, Anderson C, Sim SC, Michel A, Causse M, McSpadden Gardner B, Francis D, Van der Knaap E (2011) Distribution of SUN, OVATE, LC and FAS in the Tomato Germplasm and the Relationship to Fruit Shape Diversity. Plant Physiol. 156: 275-285.

Singh AK (2005) Genetic variability correlation and path coefficient studies in tomato (Lycopersicumesculentum Mill.) Under cold arid region of LadakhProgrne. Horticult. 37(2): $437-443$.

Singh AK (2007) Correlation and path coefficient studies in tomato (Lycopersiconesculentum Mill.) under cold arid region of Ladakh. Haryana J Horticult. 36(3\&4):346-447.

Tanksley SD (2004) The genetic, developmental and molecular bases of fruit size and shape variation in tomato. Plant Cell. 16:181-189.

Van der Knaap E, Tanksley SD (2003) The making of a bell pepper-shaped tomato fruit: Identification of loci controlling fruit morphology in Yellow Stuffer tomato. Theor Appl Genet. 107: 139-147.

Van der Knaap E and Tanksley SD (2001) Identification and characterization of a novel locus controlling early fruit development in tomato. Theor Appl Genet. 103: 353-358.

Zhang C, Tanabe K, Wang S, Tamura F, Yoshida A, Matsumoto $P$ (2006) The impact of cell division and cell enlargement on the evolution of fruit size in Pynus pyrifolia. Ann Bot. 98:537543.

Zhao K, Tung CW, Eizenga GC, Wright MH, Ali ML, Price AH, Norton GJ, Islam MR, Reynolds A, Mezey J, McClung AM, Bustamante CD, McCouch SR (2011) Genome-wide association mapping reveals a rich genetic architecture of complex traits in Oryza sativa. Nat Comm 2. Article 467. 